\title{
Nutritional balance and its relationship to yield in a coffee field: Inferences from geospatial analysis
}

\author{
Marcelo B. da Silva ${ }^{1}$, Fábio L. Partelli ${ }^{1}$, Ivoney Gontijo ${ }^{1} \&$ Marcellus M. Caldas $^{2}$ \\ ${ }^{1}$ Universidade Federal do Espírito Santo/Departamento de Ciências Agrárias e Biológicas. São Mateus, ES, Brasil. E-mail: marcelo.silva@ufes.br - ORCID: 0000- \\ 0001-8401-1804; partelli@yahoo.com.br - ORCID: 0000-0002-8830-0846; ivoney.gontijo@ufes.br (Corresponding author) - ORCID: 0000-0002-4251-4689 \\ ${ }^{2}$ Kansas State University/Department of Geography \& GeoSpatial Science. Manhattan, Kansas State, USA. E-mail: caldasma@ksu.edu - ORCID: 0000- \\ 0003-3086-7054
}

\begin{abstract}
Information obtained from studies of spatial variability and the Diagnosis and Recommendation Integrated System (DRIS) may contribute to understanding better the relationship between mineral nutrient balance and factors that limit the crop yield. This study shows that nutritionally balanced plants may be associated with low productivity in Conilon coffee fields. The study was carried out on a highly productive Conilon coffee (Coffea canephora) field, in São Mateus, state of Espírito Santo, Brazil. A sample grid was established with 100 points, each point linked to one plant. Twenty pairs of leaves from each plant were collected from productive branches to create a sample for nutritional analysis. The rust incidence (Hemileia vastatrix), the presence of the coffee borer (Hypothenemus hampei), and the physical characteristics of the soil were evaluated in each sampled plant. DRIS and Nutrient Balance Index (NBI) were calculated, and from the yield data, they were characterized using descriptive statistics. Maps were created showing the spatial distribution of the NBI, yield, total sand, and incidence of rust and coffee borer. It was verified the low relationship between nutritional balance and yield in Conilon coffee, suggesting that non-nutritional factors also influenced plant production. In areas of the maps with high NBI, the plant's nutritional balance was the main limiting factor of production, since most plants in this area produced less than the average productivity of the plants sampled. The use of a geostatistics tool combined with the NBI resulted in better understanding of the relationship between nutritional and non-nutritional variables on the Conilon coffee yield.
\end{abstract}

Key words: Coffea canephora, geostatistics, plant nutrition

\section{Balanço nutricional e sua relação com a produtividade do cafeeiro: Inferências da análise geoespacial}

RESUMO: Informações obtidas a partir de estudos de variabilidade espacial e do Sistema Integrado de Diagnose e Recomendação (DRIS) poderão contribuir para o melhor entendimento da relação entre o balanço de nutrientes e os fatores que limitam a produtividade das culturas. Este estudo mostra que plantas equilibradas nutricionalmente podem estar associadas à baixa produtividade em café Conilon (Coffea canephora). O estudo foi realizado em uma lavoura altamente produtiva de café Conilon em São Mateus, ES. Foi estabelecida uma grade amostral com 100 pontos, cada ponto relacionado a uma planta. Vinte pares de folhas de cada planta foram coletados de ramos produtivos compondo uma amostra para análise nutricional. A incidência da ferrugem (Hemileia vastatrix), a presença da broca do café (Hypothenemus hampei), e características físicas do solo também foram coletadas para cada planta amostrada. O DRIS e o Îndice de Equilíbrio dos Nutrientes (IEN) foram calculados e, com os dados de produtividade, foram caracterizados utilizando estatística descritiva. Foram criados mapas com a distribuição espacial do IEN, produtividade, areia total e incidência de ferrugem e da broca do cafeeiro. Verificou-se baixa relação entre equilíbrio nutricional e produção no café Conilon, sugerindo que fatores não nutricionais também influenciaram na produtividade das plantas. Nas áreas dos mapas com alto IEN, o balanço nutricional da planta foi o principal fator limitante da produção, pois a maioria das plantas nessa área produziu menos que a produtividade média das plantas amostradas. $\mathrm{O}$ uso de uma ferramenta geoestatística combinada com o IEN resultou em melhor compreensão da relação entre variáveis nutricionais e não nutricionais sobre a produtividade de café Conilon.

Palavras-chave: Coffea canephora, geoestatística, nutrição mineral de plantas 


\section{INTRODUCTION}

In an integrated management system, the reduction of excessive crop fertilization could be achieved using chemical analysis of soil and leaves. Whereas the chemical analysis of soil helps estimate the nutrients available to plants, foliar analysis has the advantage of indicating a plant's current nutritional status (Partelli et al., 2007). Additionally, tissue analysis is considered a more direct method to evaluate plant nutrition status than soil analysis.

Based on the leaf nutritional composition, it is possible to calculate the Diagnosis and Recommendation Integrated System (DRIS) index, which can contribute to more rational fertilization and thus improve productivity (Mourão Filho, 2004; Castamann et al., 2012, Wairegi \& Van Asten, 2012). DRIS incorporates the concept of nutritional balance, which considers all nutrients and has a negative relationship with yield. This negative relationship indicates that nutritional imbalance is a factor that limits the production of a crop (Partelli et al., 2006, 2007; Silva et al., 2013).

Variables such as diseases, row spacing, water stress, soil characteristics, and genotype also influence crop yield (Partelli et al., 2007), and they are considered non-nutritional factors. Although plants with a high imbalance index frequently had low yields (Mourão Filho, 2004), certain plants exhibit a low imbalance index combined with a low yield. It is necessary to improve our understanding of yield variability to manage fields according to plant production (Mueller et al., 2012).

The Geographic Information System (GIS) based technology (Reichardt \& Jürgens, 2009) can be used to understand the spatial yield distribution in a field (Nzeyimana et al., 2014). Farm practices are inherently spatial, and the development and visualization of a spatial database help the diagnosis of nutritional problems and improves crop yield, quality, and the management of chemical fertilization (Moreno et al., 2014).

The purpose of this paper is to contribute to this discussion by investigating the influence of both nutritional and non-nutritional factors on limiting yield in Conilon coffee (Coffea canephora Pierre ex A. Froehner) fields in Espírito Santo, Brazil. To this end, it was integrate the use of GIS and geostatistics to examine how the nutritional balance and nonnutritional factors are related to yield.

\section{Material AND Methods}

For this study, it was selected a highly productive coffee farm, with mean yield of the last three years of $6,000 \mathrm{~kg} \mathrm{ha}^{-1}$, in São Mateus, Northern Espírito Santo State, Brazil $\left(18^{\circ} 43^{\circ}\right.$ $\left.35.23^{\prime \prime} \mathrm{S}, 40^{\circ} 05^{\prime} 59.08^{\prime \prime} \mathrm{W}\right)$. The total area of the field was approximately 5.0 ha. The coffee planting occurred in March 2010 using $3.0 \times 1.0 \mathrm{~m}$ (3.333 plants $\left.\mathrm{ha}^{-1}\right)$ spacing with the genotype 'Bamburral', which belongs to the Tributum variety (Giles et al., 2019; Partelli et al., 2020). The region's climate is hot and humid (Aw-type, Köppen), with a rainy season in spring-summer and a dry season in the fall (Alvares et al., 2013). A microsprinkler irrigation system with a support system for agricultural decision (SISDA) to estimate the required irrigation based on the minimum and maximum temperatures was used to compensate for the drought stress in the dry season.

The quantity of limestone and fertilizer applied was based on recommendations for the State of Espírito Santo, Brazil (Prezotti et al., 2007), which was applied annually in the coffee canopy. The nutrients were first dissolved in water and then applied through the irrigation system monthly. The total annual amount of nutrients applied were $480 \mathrm{~kg} \mathrm{ha}^{-1} \mathrm{~N}, 33$ $\mathrm{kg} \mathrm{ha}^{-1} \mathrm{P}_{2} \mathrm{O}_{5}$ and $399 \mathrm{~kg} \mathrm{ha}^{-1} \mathrm{~K}_{2} 0$. The coffee berry borer and coffee leaf rust were controlled by applying a $3.5 \mathrm{~L} \mathrm{ha}^{-1}$ of the commercial product, imidacloprid + triadimenol, to the soil in December 2012.

In May 2012, a sample grid was established in an area of $10,000 \mathrm{~m}^{2}$ with 100 points. The minimum distance between the points was $1 \mathrm{~m}$ (Figure 1). Each grid point was georeferenced using a pair of GPS receivers (TechGeo model GTR G2 geodesic), corresponding to one plant.

In January 2013, 20 pairs of completely expanded leaves from each selected plant were collected from productive branches to obtain the samples for nutritional analysis. Nitrogen was determined by the Kjeldahl method, and P, K, Ca, $\mathrm{Mg}, \mathrm{S}, \mathrm{Fe}, \mathrm{Zn}, \mathrm{Cu}$, and $\mathrm{Mn}$ were obtained by nitro-perchloric digestion. Boron was quantified by dry-method incineration with colorimetric determination. The total elements analysis was performed based on total dry matter, as recommended by EMBRAPA (2009).

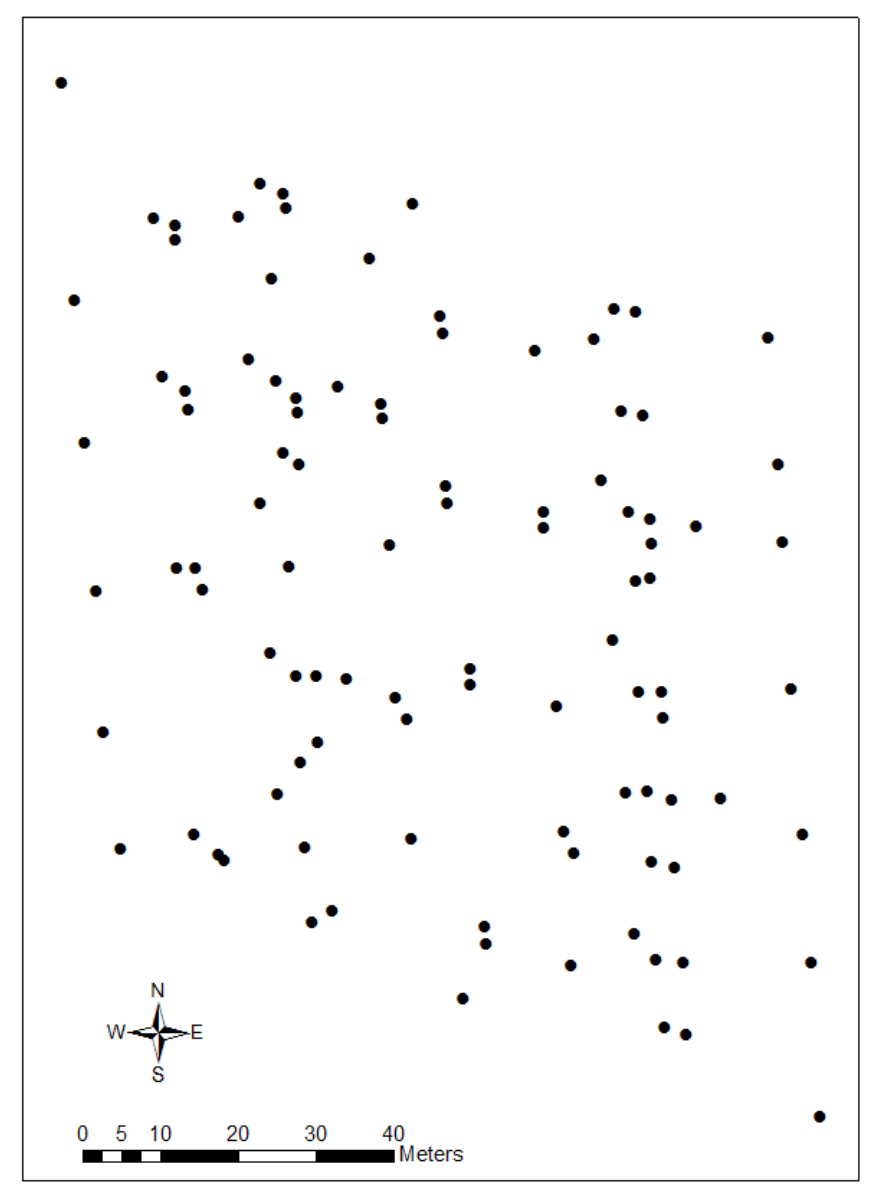

Each point represents one coffee plant

Figure 1. Representation of the 100-point sampling grid 
Coffee leaf rust (Hemileia vastatrix), coffee berry borer (Hypothenemus hampei), and the physical characteristics of the soil were sampled. Following the method recommended by EMBRAPA (1997), in March 2013, soil samples were collected in $0-20 \mathrm{~cm}$ depth to determine the amounts of clay, silt, and sand. In June 2013, the period of the year when coffee leaf rust disease is the most intensive, ten leaves were collected from the top one-third of each plant and calculated the percentage of diseased leaves. In July 2013, samples with around $0.25 \mathrm{~kg}$ of coffee fruits were collected from the upper third part of the plants and classified as drilled or not drilled to evaluate the presence of the berry borer. The final yield of each plant selected was obtained at the end of the production cycle.

DRIS was calculated according to Partelli et al. (2006) using the reduced normal relationship of the concentrations of two nutrients (Jones, 1981) and a sensibility constant of 10 .

Jones (1981) method is based on the following Eq. 1.

$$
f\left(\frac{Y}{X}\right)=\left(\frac{Y}{X_{a}}-\frac{Y}{X_{n}}\right) \frac{k}{s}
$$

where:

$\mathrm{f}(\mathrm{Y} / \mathrm{X})$ - function of the ratio of nutrients $\mathrm{Y}$ and $\mathrm{X}$;

$\mathrm{Y} / \mathrm{X}_{\mathrm{a}}$ - ratio of nutrients in the sample to be diagnosed;

$\mathrm{Y} / \mathrm{X}_{\mathrm{n}}$ - standard nutrient ratio;

$\mathrm{s}$ - standard deviation of the $\mathrm{Y} / \mathrm{X}_{\mathrm{n}}$ ratio; and,

$\mathrm{k}$ - sensitivity constant, which, in this paper, was 10.

The DRIS index of a nutrient represents the arithmetic mean of the quotients of that nutrient concentration with the concentrations of the other nutrients. In this paper, direct and inverse relations, suggested by Alvarez V. \& Leite (1999), were used, since the positive function $(\mathrm{f}=\mathrm{N} / \mathrm{P})$ represents high $\mathrm{N}$, compared to $\mathrm{P}$, and low $\mathrm{P}$ relative to $\mathrm{N}$, which contributes positively to the $\mathrm{N}$ index and negatively to the $\mathrm{P}$ index.

Thus, the DRIS index was calculated using Eq. 2.

$$
\begin{aligned}
\text { Index } X & =\left\{\left[\mathrm{f}\left(\mathrm{X} / \mathrm{Y}_{1}\right)+\mathrm{f}\left(\mathrm{X} / \mathrm{Y}_{2}\right)+\ldots+\mathrm{f}\left(\mathrm{X} / \mathrm{Y}_{\mathrm{n}}\right)\right]-\right. \\
& \left.-\left[\mathrm{f}\left(\mathrm{Z}_{1} / \mathrm{X}\right)+\mathrm{f}\left(\mathrm{Z}_{2} / \mathrm{X}\right)+\ldots+\mathrm{f}(\mathrm{Zm} / \mathrm{X})\right]\right\} /(\mathrm{n}+\mathrm{m})
\end{aligned}
$$

where:

$\mathrm{Y} 1, \mathrm{Y} 2, \ldots \mathrm{Yn}$ - nutrients that appear in the denominator of the relationships with nutrient;

$\mathrm{X} ; \mathrm{Z1}, \mathrm{Z2}, \ldots \mathrm{Zm}$ - nutrients that appear in the numerator of the relationships with nutrient $\mathrm{X}$;

$\mathrm{n}$ - number of functions where nutrient $\mathrm{X}$ appears in the numerator; and,

$\mathrm{m}$ - number of functions where nutrient $\mathrm{X}$ appears in the denominator.

The NBI is obtained by adding, in module, all the indexes involved (Sumner, 1977), and it was calculated using the equation: NBI = | index $\mathrm{x}|+|$ index $\mathrm{x}^{\prime}|+\ldots+|$ index $\mathrm{n} \mid$ where, index $\mathrm{x}$, index $\mathrm{x}^{\prime}$ and index $\mathrm{n}$, are the indexes of each nutrient involved in the diagnosis.

The nutritional status was evaluated based on regional standards for productivity coffee fields over $6,000 \mathrm{~kg} \mathrm{ha}^{-1}$ (Partelli et al., 2016).
DRIS, NBI, and yield data were characterized using descriptive statistics (mean, median, maximum, minimum, and standard deviation). Also, the correlation and the linear regression between the NBI and the yield were obtained.

The semivariogram analysis, the kriging, and the spatial distribution mapping of NBI, yield, and other variables were performed using ArcGIS software.

\section{RESULTS AND Discussion}

The descriptive statistics related to the DRIS index, NBI, and yield are presented in Table 1. Based on the DRIS mean value, it is possible to note the deficiency of certain nutrients and the excess of others. One can observe groups of plants with deficiencies of nitrogen and sulfur, with DRIS values of -13.33 and -10.04 , respectively. Plants with an excess of zinc (DRIS value: 40.51) were also observed. In contrast, the nutrient copper was in equilibrium and exhibited a mean DRIS value close to zero.

From the data dispersion and considering the maximum and minimum DRIS values for each nutrient, it can be observed that among the eleven different evaluated nutrients, nine nutrients in leaves were found with high negative DRIS values, and nine nutrients were found in plants with high positive DRIS values (Table 1). Examining 100 samples of leaves of Arabica coffee, Silva et al. (2011) observed coefficients of variation between 17.10 and $42.02 \%$ for the DRIS value. This variation in the DRIS value indicates that there is the possibility to improve the yield in a field using precision agriculture tools to correct the nutritional imbalance.

As expected, the NBI value was positive because it results from the sum of the modulus values of the DRIS index for each nutrient (Eq. 2). The high standard deviation observed in the NBI was similar to that of the DRIS for zinc, and it represents statistical evidence of a data distribution that is scattered around the mean (Gontijo et al., 2011).

The mean yield was $9.36 \mathrm{~kg}$ plant $^{-1}$ (Table 1 ), whereas the national mean of the Conilon yield is $2.8 \mathrm{~kg} \mathrm{plant}^{-1}$. The lowest observed yield was $3.0 \mathrm{~kg} \mathrm{plant}^{-1}$, which indicates that this field has high productivity and low variation (Std. Dev. $=4.01$ ).

It was verified a significant correlation between the NBI and yield (Figure 2), with a negative correlation coefficient $(r=-0.30$, $\mathrm{p}=0.05)$. Partelli et al. (2006) and Partelli et al. (2007) found a

Table 1. Descriptive statistics of DRIS, NBI, and yield $\left(\mathrm{kg} \mathrm{plant}^{-1}\right)$ data for each nutrient, considering $\mathrm{n}=100$

\begin{tabular}{|lrrrrc|}
\hline \multirow{2}{*}{ Variable } & \multicolumn{5}{c}{ Statistics } \\
\cline { 2 - 6 } & Mean & Median & Maximum & Minimum & $\begin{array}{c}\text { Standard } \\
\text { deviation }\end{array}$ \\
\hline $\mathrm{N}$ & -13.33 & -10.92 & -2.12 & -28.52 & 6.73 \\
\hline $\mathrm{P}$ & -3.65 & -3.67 & 7.83 & -21.06 & 6.28 \\
$\mathrm{~K}$ & 1.78 & 1.79 & 12.18 & -12.48 & 4.99 \\
$\mathrm{Ca}$ & 2.62 & 2.97 & 12.55 & -12.61 & 5.19 \\
\hline $\mathrm{Mg}$ & -2.93 & -2.18 & 7.73 & -15.17 & 4.35 \\
$\mathrm{~S}$ & -10.04 & -9.54 & 0.39 & -30.55 & 5.87 \\
$\mathrm{~B}$ & -4.62 & -4.34 & 6.54 & -18.93 & 4.30 \\
$\mathrm{Cu}$ & 0.82 & 0.43 & 11.89 & 8.94 & 4.39 \\
\hline $\mathrm{Fe}$ & -4.22 & -3.63 & 4.15 & -16.00 & 3.92 \\
\hline $\mathrm{Mn}$ & -6.62 & -6.05 & 6.55 & -24.24 & 6.42 \\
\hline $\mathrm{Zn}$ & 40.51 & 26.05 & 101.68 & 9.36 & 27.38 \\
\hline $\mathrm{NBI}$ & 99.94 & 79.00 & 207.08 & 47.32 & 45.11 \\
\hline Yield & 9.36 & 9.00 & 25.00 & 3.00 & 4.01 \\
\hline
\end{tabular}

DRIS - Diagnosis and Recommendation Integrated System; NBI - Nutrient Balance Index 
correlation of -0.31 in Conilon coffee and -0.24 in Arabica coffee. Silva et al. (2011) studied 100 plants from two fields with different varieties of Arabica coffee and found correlation coefficients of -0.71 and -0.31 . Based on the frequently low correlation coefficient value, one can assume that the productivity variation in coffee fields is more dependent on non-nutritional factors. Castillo et al. (2006) indicate that the effect of the biennial cycle in coffee production contributes to the low relationship between the NBI and yield. According to Castillo et al. (2006), plants with a low NBI direct their nutrients toward vegetative growth in years in which the productivity is low. The genetic variability for height presented in the Catuaí variety is another factor that contributes to the low correlation between yield and the NBI (Silva et al., 2011). Many other characteristics influence coffee yield, such as plant shape, the non-uniform maturation of the fruits (Ferraz et al., 2011), and flowering, particularly when production is estimated by considering individual plants and not the entire field.

The distribution of plants grouped based on the relationship between the yield and the NBI is shown in Table 2. Most of the plants were nutritionally balanced, and under this condition, half of the plants produced more than the mean yield and half produced less than the mean yield, which was $9.3 \mathrm{~kg}$. This distribution helps to demonstrate that random non-nutritional variables influence the plant's yield. The equilibrium only changed when the distribution of the plants associated with a high NBI was considered. In this case, the number of plants with low production was seven times more than the number of plants with a yield over the mean. This outcome indicates that for the plants with high NBI, the nutritional imbalance was the main factor that limited yield (Silva et al., 2014).

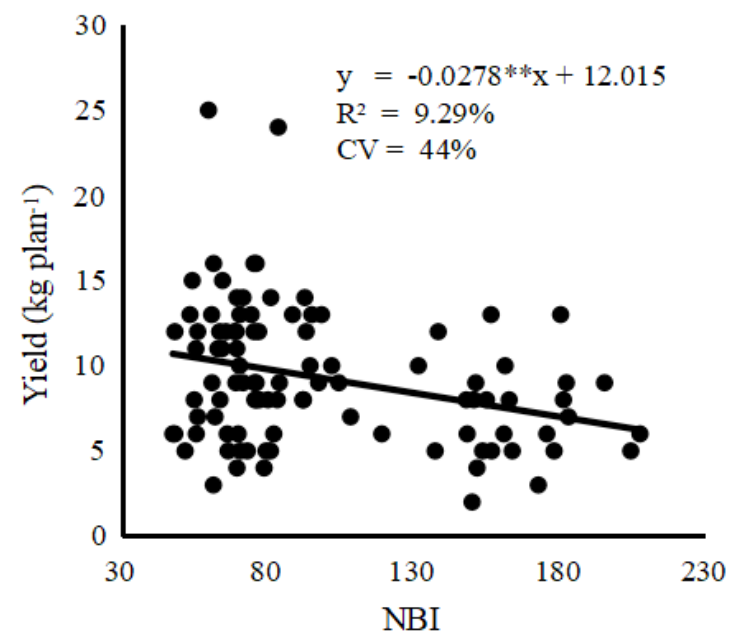

** - Significant at $\mathrm{p} \leq 0.01$ by F test

Figure 2. Relationship between the Nutritional Balance Index (NBI) and yield for Conilon coffee

Table 2. Distribution of the number of plants (percentage) according to yield $\left(\mathrm{kg} \mathrm{plant}^{-1}\right)$ and NBI

\begin{tabular}{|c|c|c|c|c|}
\hline \multirow{2}{*}{$\begin{array}{l}\text { Mean } \\
\text { Yield }\end{array}$} & \multicolumn{3}{|c|}{ NBI } & \multirow{2}{*}{ Total } \\
\hline & $\mathrm{NBI}<55$ & $55<\mathrm{NBI}<145^{\mathrm{a}}$ & $\mathrm{NBI}>145$ & \\
\hline$>9.3$ & 3.2 & 34.0 & 3.2 & 40.4 \\
\hline$<9.3$ & 4.3 & 33.0 & 22.3 & 59.6 \\
\hline Total & 7.5 & 67.0 & 25.5 & \\
\hline
\end{tabular}

${ }^{\mathrm{a}}$ Mean NBI \pm Standard Deviation; NBI - Nutrient Balance Index
The data (Table 2) are similar to the results obtained for Arabica coffee in Venezuela by Castillo et al. (2006), who tested four different methods to calculate the DRIS index. Castillo et al. (2006) observed that low NBI value was equally related to high and low yield; on the other hand, high NBI value was strongly associated with low yield. The possible relationship between high NBI and low yield in Conilon coffee also is discussed by Partelli et al. (2005).

As indicated by the semivariogram estimated for the NBI and yield (Figure 2), the DRIS index and the NBI exhibit spatial dependence but with different patterns according to the adjusted models. Both models presented a low nugget effect, which is a parameter that is related to error measurement during the data-collection process (Cambardella et al., 1994). With the adjusted semivariogram models was possible to create a map that represents the spatial patterns for yield and NBI (Figure 3).

The NBI map has $72 \%$ of its total area under the condition of nutritional balance, with NBI values ranging from 56 to 120 (Figure 4). There was only one small zone with a low NBI on the east side of the map, which represented $1.1 \%$ of the total area. Nutritional imbalance occurred in $26.9 \%$ of the map, which corresponded to the black area (Figure 4A). Around $37.4 \%$ of the plants had yield less than the average yield; they were concentrated in the area as indicated with white points
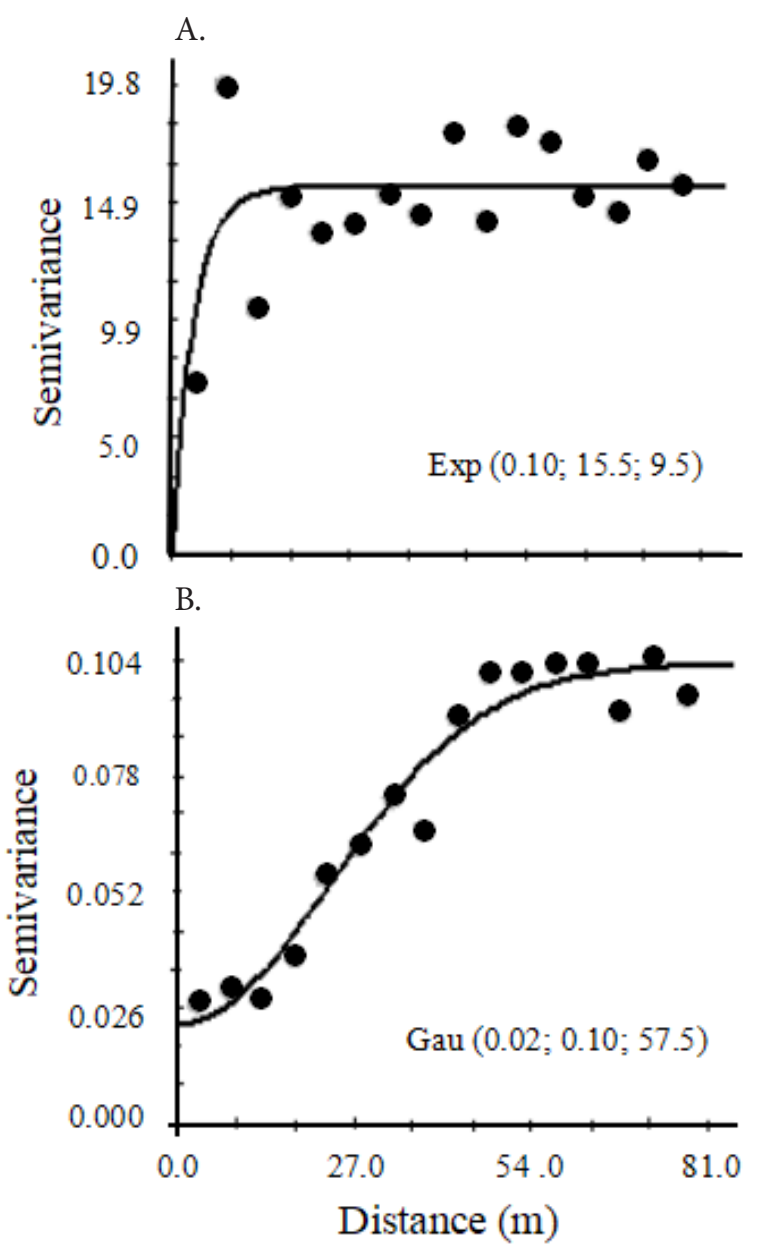

Values in parentheses are for the nugget effect $(\mathrm{Co})$, the level $(\mathrm{Co}+\mathrm{C})$, and the range (a), respectively; Exp - Exponential model; Gau - Gaussian model

Figure 3. Semivariograms models for the yield of coffee plants in the experimental field $\left(\mathrm{kg} \mathrm{plant}^{-1}\right)(\mathrm{A})$ and NBI (B) 


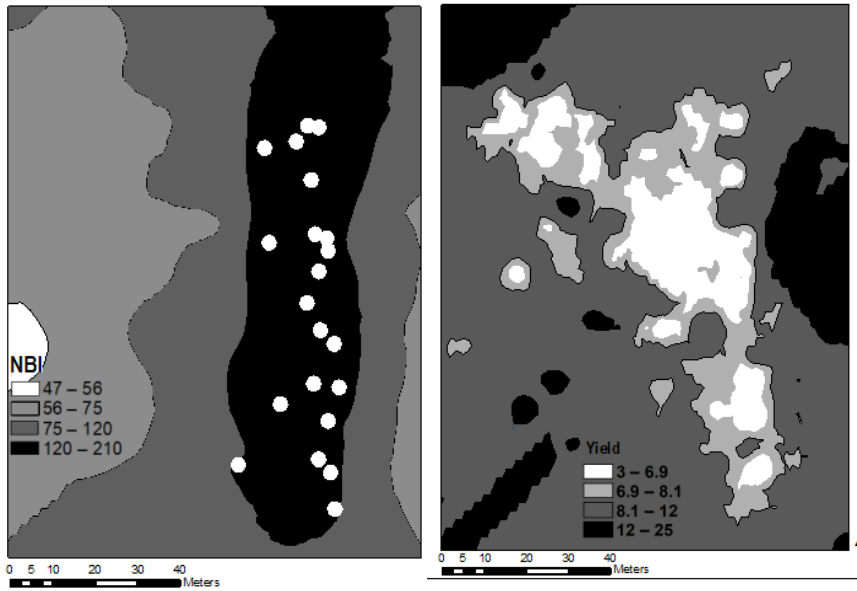

The white points in the NBI map indicate the location of the plants with NBI $\geq 145$ and yield $\leq 9.3$, as presented in Table 2

Figure 4. Spatial distribution maps of NBI (A) and yield of coffee plants in the experimental field (B) $\left(\mathrm{kg} \mathrm{plant}^{-1}\right)$

(Figure 4A). The north-south distribution of the NBI zone had the same direction of the fertigation system pipes. The NBI method revealed the effect of fertilization management. According to the map, with an adjustment in the fertilization and irrigation management used in the plantation, it is possible to decrease the nutritionally unbalanced area and consequently improve the total mean production of the field.

The yield map showed one zone with low yield (which ranged from 3.0 to $8.1 \mathrm{~kg} \mathrm{plant}^{-1}$ ) that also exhibited a northsouth pattern (Figure 4B) and was located close to the NBI black zone (Figure $4 \mathrm{~A}$ ). These characteristics indicate that the high NBI area influenced this low yield zone. From a different perspective, it is important to note another area of low yield, which was located on the northwest side of the yield map. In this area, the NBI ranges from 56 to 120; that is, these plants have a moderate nutritional balance and should produce more than was observed. Despite the complexity of the factors involved in plant production (Frogbrook et al., 2002), the presence of an area of plants with low yield implies that a non-nutritional condition influences the yield of these plants.

The effect of soil attributes on yield variation may be perceived when the data from soil attributes are overlaid on the yield data (Zaman \& Schumann, 2006). Maps were created using data collected during the experiment to determine a non-nutritional factor associated with the observed low yield area (Figure 5). Based on the maps presented in Figure 5, an area with a high concentration of sand could be associated with the low yield area in Figure 4B. Typically, a high sand concentration is associated with water or nutritional stress (Zaman \& Schumann, 2006). Thus, water stress may be the main factor that limited the yield of the plants located on the northwest side (Figure 4B). Water stress has been demonstrated to be an important limiting factor for Conilon coffee (Covre et al., 2016). The region in which the experiment was conducted is characterized by low available water, with annual rainfall from 200 to $400 \mathrm{~mm}$. Considering that irrigation was applied according to the requirements of the total area of the field, it can be expected that the plants located in the area with the highest amount of sand would suffer more water stress than the other plants in the field.
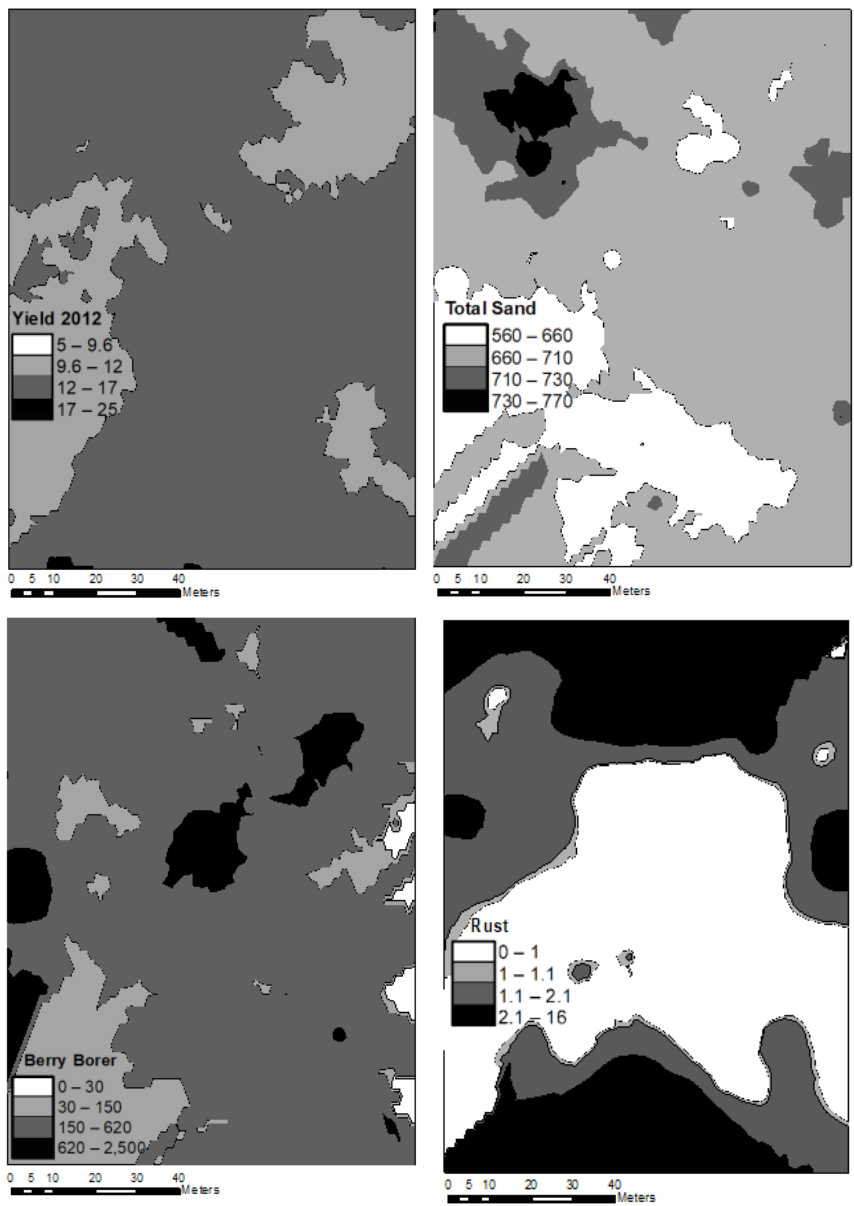

Figure 5. Spatial distribution maps of yield $\left(\mathrm{kg} \mathrm{plant}^{-1}\right)$ (2012), total sand $\left(\mathrm{g} \mathrm{kg}^{-1}\right)$, coffee berry borer (number bored of fruits), and coffee leaf rust (\%)

\section{Conclusions}

1. The correlation between nutritional balance and yield was low, which indicates that for the studied Conilon coffee area, non-nutritional factors influence the individual plant production.

2. In the area with high NBI, the plant nutritional balance is the largest limiting factor relative to yield, which indicates that most of the plants in this area produced less than the average yield of the entire field.

3. GIS technology enabled the identification of nonnutritional yield factors that limited the crop harvest in an area in which the nutritional condition was balanced.

4. The use of a geostatistics tool combined with the NBI resulted in an improved understanding of the influence of nutritional and non-nutritional variables on yield variability in a Conilon coffee plantation.

\section{Literature Cited}

Alvares, C. A.; Stape, J. L,; Sentelhas, P. C.; Gonçalves, J. L. M.; Sparovek, G. Koppen's climate classification map for Brazil. Meteorologische Zeitschrift, v.22, p.711-728, 2013. https://doi. org/10.1127/0941-2948/2013/0507

Alvarez V., V. H; Leite, R. A. Fundamentos estatísticos das formulas usadas para cálculo dos índices DRIS. Boletim Informativo da Sociedade Brasileira de Ciência do Solo, v.24, p.20-25, 1999. 
Cambardella, C. A.; Moorman, T. B.; Novak, J. M.; Parkin, T. B.; Karlen, D. L.; Turco, R. F.; Konopka, A. E. Field-scale variability of soil properties in central Iowa soils. Soil Science Society of America Journal, v.58, p.1501-1511, 1994. https://doi.org/10.2136/ sssaj1994.03615995005800050033x

Castamann, A.; Escosteguy, P. A. V.; Berres, D.; Zanella, S. Diagnosis and recommendation integrated system (DRIS) of soybean seed oil content. Revista Brasileira de Ciência do Solo, v.36, p.18201827, 2012. https://doi.org/10.1590/S0100-06832012000600016

Castillo, M. A.; Rodríguez, V.; Rodríguez, O. Normas e indices DRIS para evaliuación nutritional del cafeto. Acta Cientifica Venezolana, v.57, p.59-65, 2006.

Covre, A. M.; Partelli, F. L.; Bonomo, R.; Braun, H.; Ronchi, C. P. Vegetative growth of Conilon coffee plants under two water conditions in the Atlantic region of Bahia State, Brazil. Acta Scientiarum Agronomy, v.38, p.535-545, 2016. https://doi. org/10.4025/actasciagron.v38i4.30627

EMBRAPA - Empresa Brasileira de Pesquisa Agropecuária. Manual de métodos de análise de solos. Brasília, Brazil: Centro Nacional de Pesquisa de Solos, 1997. 212p.

EMBRAPA - Empresa Brasileira de Pesquisa Agropecuária. Manual de análises químicas de solos, plantas e fertilizantes. Rio de Janeiro, Brazil: Centro Nacional de Pesquisa de Solos, 2009. 627p.

Ferraz, G. A. e S.; Silva, F. M. da; Alves, M. de C.; Bueno, R. de L.; Costa, P. A. N. da. Geostatistical analysis of fruit yield and detachment force in coffee. Precision Agriculture, v.13, p.76-89, 2011. https:// doi.org/10.1007/s11119-011-9223-8

Frogbrook, J. L.; Oliver, M. A.; Slahi, M.; Ellis, R. H. Exploring the spatial relations between cereal yield and soil chemical properties and the implications for sampling. Soil Use and Management, v.18, p.1-9, 2002. https://doi.org/10.1079/SUM2002086

Giles, J. A. D.; Ferreira, A. D.; Partelli, F. L.; Aoyama, E. M.; Ramalho, J. C.; Ferreira, A.; Falqueto, A. R. Divergence and genetic parameters between Coffea sp. genotypes based in foliar morpho-anatomical traits. Scientia Horticulturae, v.245, p.231-236, 2019. https://doi. org/10.1016/j.scienta.2018.09.038

Gontijo, I.; Dias Junior, M. S.; Guimarães, P. T. G.; Oliveira, M. S.; Ajayi, A. E. Spatial patterns of preconsolidation pressure and soil moisture along transects in two directions under coffee. Revista Brasileira de Ciência do Solo, v.35, p.1189-1196, 2011. https://doi. org/10.1590/S0100-06832011000400012

Jones, W. W. Proposed modifications of the diagnosis and recommendation integrated system (DRIS) for interpreting plant analyses. Communications in Soil Science Plant Analysis, v.12, p.785-794, 1981. https://doi.org/10.1080/00103628109367194

Moreno, F. R.; Lukas, V.; Neudert, L.; Dryslová, T. Spatial interpretation of plant parameters in winter wheat. Precision Agriculture, v.15, p.447-465, 2014. https://doi.org/10.1007/s11119-013-9340-7

Mourão Filho, F. A. A. DRIS: Concepts and applications on nutritional diagnosis in fruit crops. Scientia Agricola, v.61, p.550-560, 2004. https://doi.org/10.1590/S0103-90162004000500015

Mueller, N. D.; Gerber, J. S.; Johnston, M.; Ray, D. K.; Ramankutty, N.; Foley, J. Closing yield gaps through nutrient and water management. Nature, v.490, p.254-257, 2012. https://doi. org/10.1038/nature11420
Nzeyimana, I.; Hartemink, A. E.; Geissen, E. GIS-Based Multi-criteria analysis for arabica coffee expansion in Rwanda. Plos One, v.9, p. 1-12, 2014. https://doi.org/10.1371/journal.pone.0107449

Partelli, F. L.; Giles, J. A. D.; Oliosi, G.; Covre. A. M.; Ferreira, A.; Rodrigues, V. M. Tributun: a coffee cultivar developed in partnership with farmers. Crop Breeding and Applied Biotechnology, v.20, p.1-4, 2020. https://doi.org/10.1590/198470332020v20n2c21

Partelli, F. L.; Gomes, W. R.; Oliveira, M. G.; Dias, J. R. M.; Espindula, M. C. Normas foliares e diagnóstico nutricional do cafeeiro conilon na pré-florada e granação, no Espírito Santo. Coffee Science, v.11, p.544-554, 2016.

Partelli, F. L.; Vieira, H. D.; Carvalho, V. B.; Mourão Filho, F. A. A. Diagnosis and recommendation integrated system norms, sufficiency range, and nutritional evaluation of Arabian coffee in two sampling periods. Journal of Plant Nutrition, v.30, p.16511667, 2007. https://doi.org/10.1080/01904160701615525

Partelli, F. L.; Vieira, H. D.; Costa, A. N. Diagnóstico nutricional em cafeeiro conilon orgânico e convencional no Espírito Santo, utilizando DRIS. Ciência Rural, v.35, p.1456-1460, 2005. https:// doi.org/10.1590/S0103-84782005000600038

Partelli, F. L.; Vieira, H. D.; Monnerat, P. H.; Viana, A. P. Comparação de dois métodos DRIS para diagnóstico de deficiências nutricionais do cafeeiro. Pesquisa Agropecuária Brasileira, v.41, p.301-306, 2006. https://doi.org/10.1590/S0100-204X2006000200015

Prezotti, L. C.; Gomes, J. A.; Dadalto, G. G.; Oliveira, J. A. Manual de recomendação de calagem e adubação para o Estado do Espírito Santo: 5. aproximação. Vitória, Brazil: SEEA/INCAPER/ CEDAGRO, 2007. 305p.

Reichardt, M.; Jürgens, C. Adoption and future perspective of precision farming in Germany: Results of several surveys among different agricultural target groups. Precision Agriculture, v.10, p.73-94, 2009. https://doi.org/10.1007/s11119-008-9101-1

Silva, E. B.; Farnezi, M. M. M.; Pinto, N. A. V. D; Graziotti, P. H. Dris norms and critical nutrients ranges for coffee beverage quality in high jequitinhonha valley, Brazil. EJBS, v. 6, p. 39-44, 2013.

Silva, R. A.; Creste, J. E.; Tiritan, C. J.; Guerra, W. E. X.; Ecker, A. E. A. Nutritional diagnosis by Dris method of the cultivars coffee in the northern region of Paraná, Brazil. Coffee Science, v. 10, p. 204-213, 2015.

Silva, S. A.; Lima, J. S. S.; Queiroz, D. M. Spatial variability in nutritional status of arabic coffee based on Dris index. Revista Ceres, v.58, p.256-261, 2011. https://doi.org/10.1590/S0034737X2011000200019

Sumner, M. E. Use of the DRIS system in foliar diagnosis of crops at high yield levels. Communications in Soil Science Plant Analysis, v.8, p.251-268, 1977. https://doi.org/10.1080/00103627709366718

Wairegi, L. W. I; Van Asten, P. J. A. Norms for multivariate diagnosis of nutrient imbalance in arabica and robusta coffee in the east african highlands. Experimental Agriculture, v. 48, p. 448-460, 2012. https://doi.org/10.1017/S0014479712000142

Zaman, Q.; Schumann, A. W. Nutrient management zones for citrus based on variation in soil properties and tree performance. Precision Agriculture, v.7, p.45-63, 2006. https://doi.org/10.1007/ s11119-005-6789-z 